\title{
INDONESIAN JOURNAL OF INTERDISCIPLINARY IsLAMIC STUDIES
}

\section{(IJIIS)}

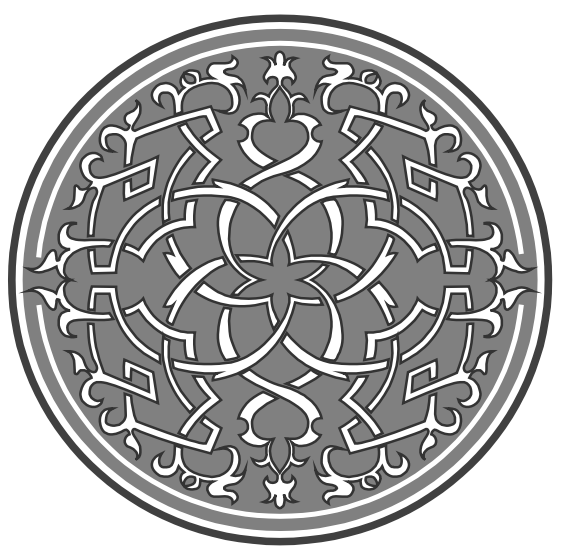

The Indonesian Journal of Interdisciplinary Islamic Studies, published biannually by the Doctoral Program in Islamic Law, Islamic University of Indonesia, serves as a platform for intellectual exchanges and interdisciplinary studies on various aspects of Islam including, but not limited to, theology, law, education, economy and politics and how they are historically and contingently embedded, expressed and articulated in a variety of historical contexts. The journal welcomes contributions from scholars and researchers of various disciplinary backgrounds in the form of original (theoretical or empirical) research articles on various issues related to Islam in both its normative and historical dimensions. 


\title{
INDONESIAN JOURNAL OF INTERDISCIPLINARY IsLamic STUdies (IJIIS)
}

\section{Vol. 1, No. 1, September 2017}

\section{ISSN 2597 - 9698}

\author{
Editor in Chief \\ Hujair AH Sanaky \\ Deputy Editor in Chief \\ Yusdani \\ Managing Editors \\ Supriyanto Abdi \\ M. Miqdam Makfi
}

\section{International Editorial Boards}

Prof. Dr. Jasser Auda (Maqasid Institute, UK)

Dr. Habib-ur-Rehman (International Islamic University, Pakistan).

Prof. Dr. Shofian Ahmad (Universiti Kebangsaan Malaysia, Kuala Lumpur).

Prof. Dr. Mohd. Mahfud MD, SH, SU (Islamic University of Indonesia, Indonesia).

Prof. Drs. Akh.Minhajie, MA, Ph.D (Sunan Kalijaga State Islamic University, Yogyakarta, Indonesia). Prof. Dr. Muhammad Amin Suma, SH, MA (Syarif Hidayatullah State Islamic University, Jakarta, Indonesia).

Prof. Srawut Aree, MA., Ph.D (Chulalongkorn University, Thailand).

Prof. Dr. Amir Mu'allim, MIS (Islamic University of Indonesia, Indonesia).

Prof. Dr. Khoiruddin Nasution, MA (Sunan Kalijaga State Islamic University, Yogyakarta, Indonesia). Prof. Dr. Juhaya S. Praja, MA (Sunan Gunung Djati State Islamic University, Bandung, Indonesia).

Prof. Dr. Tahraoui Ramdane (International Islamic University Malaysia, Malaysia).

Dr. Tlili Mounir (Zaitunah University, Tunis, Tunisia).

Hesham Khedr, Ph.D (Egyptian Association For Science, Engineering \& Environmental Issues, Egypt.)

Dr. Bertholomeus Bolong, OCD (San Pedro University, Kupang, Indonesia)

Dr. Fredrik Y.A. Doeka (Christian University Of Artha Wacana, Kupang, Indonesia)

\section{Assistants to Editors}

Muhammad Irham Roihan

Muhammad Iqbal Juliansyahzen

Language Advisors

Yuli Andriansyah

Erni Dewi Riyanti

\section{Editorial Office:}

Indonesian Journal of InTERdisciplinary IsLamic Studies (IJIIS)

Demangan Baru No. 24 2nd floor, Yogyakarta, Indonesia

Telp./ Fax. +62 274523637

Email : ijiismsi@gmail.com

Website : http://journal.uii.ac.id/index.php/IJIIS 


\section{CONTENTS}

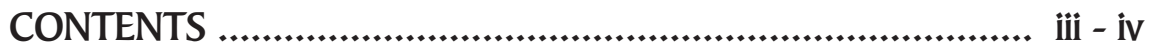

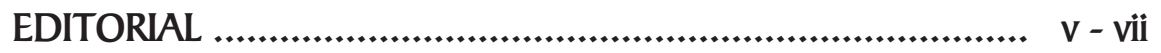

RECONFIGURING ISLAMIC DISCOURSE ON RELIGIOUS

FREEDOM AND THE RIGHTS OF RELIGIOUS MINORITIES:

Progressive Muslim Perspective

Yusdani

$1-26$

UNDERSTANDING RELIGION-STATE RELATIONS IN MUSLIM

SOCIETIES: Beyond Essentialist and Secular-Liberal Narratives

Supriyanto Abdi

CONTRIBUTION OF ISLAMIC CIVILISATION TO SCIENCE EDUCATION AND TECHNOLOGY:SOME FRESH INSIGHTS

Hamid Naseem Rafiabadi

THE ROLE OF RELIGIOUS EDUCATION IN FORMING TOLERANT INDIVIDUALS

Hujair AH Sanaky

SOCIOLOGICAL DISCOURSE IN THE QUR'AN:

Human Relation from Perspective of Sociological Establishment

Sohirin Muhammad Solihin, Layth Suud Jasim $91-108$ 
iv Vol. 1, No. 1, September 2017

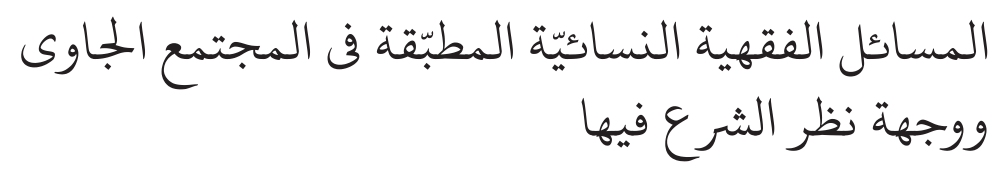

Mualimin Mohd Sahid, Mohd Faisal bin Mohamed,

Mesbahul Hoque

$$
\text { ولالة إشارة النص وآثارها فى فهم النصوص الشرعية }
$$

Hijrian A. Prihantoro

\section{BOOK REVIEW}

The Journey of Ummah

M. Irham Roihan, Nafi'atul Munawwaroh

$171-176$

Contributors Guidelines 


\section{The Journey of Ummah}

$\begin{array}{ll}\text { Title book } & : \text { Dinamika Sejarah Umat Islam Indonesia } \\ & \text { (The Dynamics of History of Islamic Society in Indonesia) } \\ \text { Writer } & : \text { Kuntowijoyo } \\ \text { Publisher } & : \text { Mata Bangsa, Yogyakarta } \\ \text { Year Publishing } & : \text { First edition : June } 2017 \\ \text { Pages } & : \mathrm{i}-\mathrm{x}+203\end{array}$

\section{Introduction}

All human being is facing a "historical process." In the process of history, many dynamics have occurred in both the in concreto and in abstracto> worlds. Indonesian Muslims have also undergone the same thing, and in this important work, Kuntowijoyo attempts to map out the historical journey of Indonesian Muslims, using structural and cultural analysis that can explain the various essential roles of in this country. .

The development of Islam in Indonesia gives the massive impact on the Indonesian history. The Dynamics of the History of Islamic Society in Indonesia is one of important works of Kuntowijoyo that was first published in 1985 covering his articles he wrote during 1984 - 1985 and then republished in 2017. This book portrays the development of Islamic society in Indonesia with a unique point of view. The author used sociocultural and socio-economic perspective to analyze the history of Islamic civilization from the early stage until the industrialization era, which rarely becomes the concern of intellectuals in Indonesia.

Kuntowijoyo was one of outstanding historian, professor in Gadjah Mada University, Muhammadiyah activist and a humanist. His works 
during his life consist of novels, short stories, poems, histories and Islamic thoughts such as Budaya dan Masyarakat (1987), Paradigma Islam: Interpretasi Untuk Aksi (1991), Identitas Politik Umat Islam (1997), Islam sebagai Ilmu (2004), and many others.

According to Kuntowijoyo, history has prophetical means. It does not only explain social transformation but also gives the spirit of change; history leads the transformation based on the society's goals of transformation, which are compatible with the purpose (mission) of Islamic history. ${ }^{1}$ In this book, Kuntowijoyo applies social science and the value of tauhid as the primary framework of analysis on the establishment of an Islamic society.

Kuntowijoyo was well-known for his perspective of the middle way or Islamic objectification. It means he neither support the idea of secularism nor Islamization. Religion is supposed live in not only the private space but also public space. ${ }^{2}$

\section{The Journey of Islamic Society in Indonesia}

The author begins his analysis by portraying the character of Islam in Indonesia which already changed from its original place, the Middle East. Islam in Indonesia had grown in an agrarian society with its specific nature: static and immobile.

He divides the phase of the history of Islamic society in Indonesia into three periods: the period of utopia, the period of ideology, and the period of the idea. In the utopian era, the form of Islamic society is patrimonial. The people's life was driven by the mites or religiousmistic beliefs. Whereas, in the ideological period, Islamic Society (ummah) began to organize themselves into ideological movements,

\footnotetext{
${ }^{1}$ Miftahuddin, Ajat Sudrajat, and Djimarwan, Kuntowijoyo dan Pemikirannya: Dari Sejarawan sampai Cendekiawan, (The Research Report, Historical Science Study Program, Major of Historical Education, Social Science Faculty, Universitas Negeri Yogyakarta, 2014), p. 24.

${ }^{2}$ Adif Fahrizal, Mengingat Kembali Objektifikasi-Islam Dr. Kuntowijoyo, accessed from http://www.civicislam.id/2015/12/mengingat-kembali-objektifikasi-islam.html
} 
for instance, Serikat Islam (SI) and Masyumi. In the period of idea or knowledge, science and thought had already developed. In this period, everything should be analyzed in the detail more practical to solve the problems or the impasse. This period is characterized by the specialization in Islamic knowledge, the rapid growth of Islamic universities, the development of Islamic economy and so on.

The discourse about technocratic society in this book is quite a concern. This is understandable, bearing in mind that in mind, that this book was written and published in the New Order,when industrialization and technocratic society were being developed. In this era, industrialization determined the religious life in the society, such as the growth of the idea of secularism inside ummah and the role of capital toward the political map in Indonesia. The ruling class starts to involve in a big business domain, to gain their own economic interest. Hence, the conflict of class become greater. The shift of society's values is inevitable. Materialism and economic rationalism drive the technocratic society, so there is no place for the transcendent social thought (social thought based on tawhid)

Unfortunately, Islamic movement that work to build up the expected Islamic society always get into the schism. The movements like Serikat Islam (SI) and Masyumi which got their heyday as the ideological organization at that time, eventually divided into two big factions: integrationist that merged with the nationalist movements and isolationist that seceded from the nationalist then become the exclusive Islamic movement. The schism is the biggest factor of undeveloped and attenuation of the Islamic movement, even shoved from national political life. Even though, there was the role of political parties like NU, PSII, PERTI, but they only had an insignificant role. The absence of the concept of socioeconomic become one of the causes of schism within the ummah. When the discourse of Islamic society's development has not been well-formed, the Islamic movement tends to lose their social bases, like what happened in the case of SI and Masyumi. 
Kuntowijoyo recommends to bring back the pattern of Islamic movement through an integrationist yet systematical approach, such as the pattern of SI and Masyumi movement during their heyday. Systematical movement means it courageously takes a side during the development era which creates a deep social gap in the society. The role of Muslim intellectuals is the key to the development of science, the idea of Islamic society and the goals of tawhid. The mosques are supposed to be the basis of the Islamic movement in social transformation. The role of masjid recently was reduced only for the individual worship aspects, for instance, shalah. Meanwhile, masjid in the Prophet's era had the bigger role, even masjid became the basis of sociocultural and socioeconomic activities. By revitalizing musyarakah as the socioeconomic work, masjid will become the center of social transformation.

\section{Quo Vadis the Future of Ummah in Indonesia}

Even though the background of book's writing was in the New Order, Kuntowijoyo gave an outstanding analysis and critical reflection of the development of Islamic society. Thus, this book is still relevant to be the core of historical study and Islamic thought. Sociocultural and economic perspective as the approach of the historical Islamic society study is the excellent point of this book. This is because this kind of thought is rarely written by contemporary Muslim intellectuals in Indonesia.

Social phenomena like the severe social fragmentation, the schism of the ummah, and the shift of core Islamic movement into pragmatical politics are supposed to get serious attention. There is no clear position of our ummah in the social gap problem. The religious domain ends up with the individual worship aspects and forgetting the social worship aspect. This apathy behavior and the shift of worship orientation precisely cause a severe social gap. Meanwhile, in term of economical power, our society become better. For instance, in 2015 and 2016, based on the data of the Ministry of Religious Affairs 
approximately 155.000 to 156.000 Muslims went to pilgrimage (hajj). Every single person needs about 34 million rupiahs for hajj. And, many of our people go to Hajj and Umrah more than once. Nevertheless, the better economic power of our society cannot cut the level of social gap because there is no collective awareness of Ummah to organize and distribute their wealth in order to solve the socio-economic problems.

The condition of the Islamic society, its nature, culture and movements from the early stage until the present era is supposed to to reflect on ummah's journey and to formulate the solution and the future movement. Islamic movement is supposed to ignore the sectoral ego or several parties' interest to achieve the greater purposes. Therefore, social problem like socioeconomic gap can be reduced. The movement of SI and Masyumi of their heyday were supported by a various level of society: from the element of labors and peasants, middle class, and upper class. The Islamic movement did not merely focus on elite political struggle or particular groups, but also to defend the rights of marginalized people. Hence, the foundation of the movement will become stronger by the support of various elements as the social basis.

The digital era influences the pattern of people's life which differs from the earlier era. The negative impact of media and information in the digital era for our ummah is the lost of identity. For instance, the shifting function of religion as media of commercialization, thus the spirit of ummah become materialistic and worldly orientation. ${ }^{3}$ Besides that, the role of media in social segregation is relatively high. Mass media and social media, drive the schism of society into various faction caused by the hoax and the open conflict in the media.

Therefore, Islamic society should re-formulate the movement pattern in the digital era. This book provides the paramount reference of social condition and its analysis from every period, which can be the future improvement of Ummah to adjust the changes and establish the better movement.

${ }^{3}$ Ahmad Rizky M. Umar, Nalar Kritis Muslim Abad XXI, (Surabaya: SAGA, 2017), p. 102. 


\section{M. Irham Roihan, Nafi'atul Munawwaroh}

The weakness of this book is that it is less comprehensive and on its historical description and analysis because the book was adapted from the articles. However, readers can enjoy this book because the systematical language in this book is easy to follow, accessible and straight to the points. Therefore, this book provides firm yet brief historical description and reflection.

\section{Irham Roihan and Nafi'atul Munawwaroh}

Student of Postgraduate Programme Faculty of Law, Islamic University of Indonesia, Yogyakarta

Email:irhamroihan@gmail.com and nafimun@gmail.com 